\title{
PELATIHAN MEDIA SOSIAL INSTAGRAM UNTUK SARANA PROMOSI EKOWISATA
}

\author{
Muhammad Hasyimsyah Batubara ${ }^{1}$, Nurmalina², Awal Kurnia Putra Nasution ${ }^{3}$, \\ Agusmawati $^{4}$, Ayu Maharani ${ }^{5}$ \\ 1,2,3,4,5 Institut Agama Islam Negeri Takengon, Aceh, Indonesia \\ email: muhammad.hasyimsyahbatubara@gmail.com ${ }^{1,4,5}$, nurmalina125@gmail.com², \\ awalkpn@gmail.com ${ }^{3}$
}

\begin{abstract}
Along with the times in this globalization era, social media is a very immediate necessity for the wider community. The utilization of social media, especially Instagram, is something that many people commonly use for various positive things. Tanoh Gayo is a natural beauty area, so it is a tourist destination whose potential is for local visitors and foreign tourists. To introduce these tourist spots, it needs promotional efforts that are cheap but universally reaching, and social media can be used for this. This program aims to help the ecotourism business manager of Tanoh Gayo carry out promotions with the media of Instagram.
\end{abstract}

Keywords: Social Media, Instagram, Ecotourism, Tanoh Gayo

\begin{abstract}
Abstrak: Bersamaan dengan pertubuhan jaman di era globalisasi ini, penggunaan media sosial menjadi kebutuhan yang sangat dekat bagi masyarakat luas. Pemanfaatan dan penggunaan media sosial, khususnya Instagram sebagai suatu hal yang lazim digunakan banyak orang untuk berbagai hal yang sifatnya positif. Tanoh Gayo menjadi salah satu wilayah yang menyimpan keindahan alam, sehingga menjadikannya sebagai tujuan wisata, yang potensinya tidak hanya untuk pengunjung lokal, namun bisa juga dikembangkan untuk wisatawan asing. Untuk memperkenalkan tempat-tempat wisata ini perlu usaha promosi yang murah namun menjangkau secara universal, media sosial bisa dimanfatkan untuk hal tersebut. Adapan tujuan program ini adalah membantu pengelola usaha ekowisata di tanoh Gayo melakukan promosi dengan media sosial Instagram.
\end{abstract}

Kata Kunci: Media Sosial, Instagram, Ekowisata, Tanoh Gayo

\section{Pendahuluan}

Destinasi pariwisata merupakan suatu kawasan atau wilayah yang menyuguhkan berbagai hal yang menarik bagi wisatawan lokal maupun luar, dikemas baik berupa wisata kuliner, wisata religi, wisata alam dan sebagainya. Destinasi pariwisata sejatinya harus memiliki daya tarik tersendiri untuk memberikan kesan yang menarik bagi wisatawan. Sejak beberapa tahun yang lalu, objek wisata menjadi salah satu solusi yang diminati oleh masyarakat untuk mengisi waktu luang dan menghilangkan kepenatan hidup. Dilain sisi parwisata juga mampu mengangkat perekenomian daerah dengan melibatkan jejaring sektor masyarakat pelaku usaha, seperti trasportasi, home stay, dan lainya. Di Indonesia sendiri menurut data BPS tahun 2018 terjadi peningkatan $12 \%$ di sektor parwisata dibandingkan tahun sebelumnya (BPS RI, 2018).

Tren wisata sebagai penopang perekonomian banyak dilirik negara maju sebagai aset yang harus dikelola dengan baik, berbagai negara yang memiliki destinasi pariwisata berlomba dengan strategi dan konsep pengembangan sektor pariwisatanya untuk menarik para wisatawan lokal maupun wisatawan asing. Mahbubani (2013) dalam Rahmiati dan Winata (2020) menyebutkan sektor pariwisata dewasa ini merupakan salah satu sektor yang cepat berkembang dan terbesar dalam perekonomian global. 
Begitu juga dengan Indonesia, dimana merupakan salah satu negara yang memiliki destinasi pariwisata yang beragam di berbagai provinsi yang ada. Pemerintah pusat dan daerah sejatinya mendorong dan mempasilitasi masyarakat dan pelaku usaha wisata untuk mengembangkan potensi-potensi dari destinasi pariwisatanya guna untuk menarik minat wisatawan. Banyak tempat-tempat wisata yang ada diaerah belum diketahui masyarakat luas, seperti Takengon atau dataran tinggi Gayo merupakan salah satu kota dengan ciri khas dingin, dimana memiliki banyak ciri tersendiri yang menonjol seperti kerajinan, kuliner, kopi, festival pacuan kuda dan yang akhir-akhir ini yang menarik minat dari banyak kalangan ialah destinasi ekowisata, wisata halal atau wisata syariahnya. Destinasi pariwisata di Gayo tidak kalah menarik dan indah dari destinasi pariwisata yang ada diluar, didukung oleh atmosfir yang sejuk menjadikan kota Takengon sebagai destinasi favorit yang tentunya berpotensi besar untuk menjadi suatu kawasan yang akan berkembang sehingga mendatangkan wisatawan asing maupun lokal.

Destinasi pariwisata yang kerap kali dikunjungi oleh wisatawan adalah danau maupun perbukitan yang membentang diwilayah Takengon. Untuk sampai ketujuan pariwisata yang akan dikunjungi kita disuguhkan pemandangan yang sangat indah. Setiap wisatawan yang datang tak lepas dari mengabadikan momen melalui foto bahkan video. Namun keindahan parwisata yang ada ini secara masif belum mampu mendongkrak perekonomian masyarakat sekitar, salah satu penyebabnya adalah kurangnya minat wisatawan lokal maupun luar yang berkunjung. Perlu usaha yang ekstra untuk memperkenalkan destinasi wisata yang ada ini, salah satu usaha yang dapat dilakukan dengan memperkenalkan nilai keunikan dan keindahannya dengan menggunakan media sosial. Dimana media sosial memiliki jangkauan yang luas yang dapat ditangkap oleh semua orang di berbagai wilayah. Media sosial secara luas harus dimanfaatkan untuk menghemat biaya promosi parwisata yang ada didaerah, dengan penggunaan media sosial seperti kanal facebook, instagram, bahkan youtube memberikan pengaruh bagi wisatawan untuk mengunjungi destinasi tersebut. Pada akhirnya tempat-tempat wisata di daerah, seperti parwisata dataran tinggi Gayo bisa di perkenalkan ke masyarakat luas. Menurut Wibowo, 2012; Arifianto \& Coiri, 2018; Barovih \& Nurussama, 2018; Sunarti, Puspita, \& Ernawati, 2018; Helmalia \& Afrinawati, 2018 media online berbasis website mempunyai pengaruh terhadap peningkatan penjualan, hal ini tentu juga relevan diterapkan untuk memperkenalkan destinasi wisata yang ada. Lebih lajut secara spesifik Fatani dan Suyadnya 2015; Kurniawati, 2016; Atiko et al., 2016; Sukoco, 2017; Satvikadewi \& Hamim, 2018; Purnomo, 2018; Trihayuningtyas et al,. 2018; Fauziah et al., 2018 dalam Pratiwi dan Madanacaragni, 2020 menyatakan media sosial khususnya Instagram sahih menyandang dampak yang berarti dalam menaikkan angka pariwisata. Untuk itu penting melakukan pendampingan dan pelatihan bagi pelaku usaha wisata tradisional yang ada di Gayo untuk mampu memanfaatan media sosial, khususnya Instagram sebagai sarana promosi destinasi ekowisata yang ada di Aceh Tengah. 


\section{Metode}

Metode kegiatan yang digunakan untuk mencapai tujuan dalam pengabdian ini adalah melalui pendekatan pelatihan dengan memperkenalkan keterampilan membuat dan mengelola media Instagram bagi pengelola tempat ekowisata di Aceh Tengah. Alur pelaksanaan pengabdian dapat dilihat melalui beberapa tahapan yaitu:

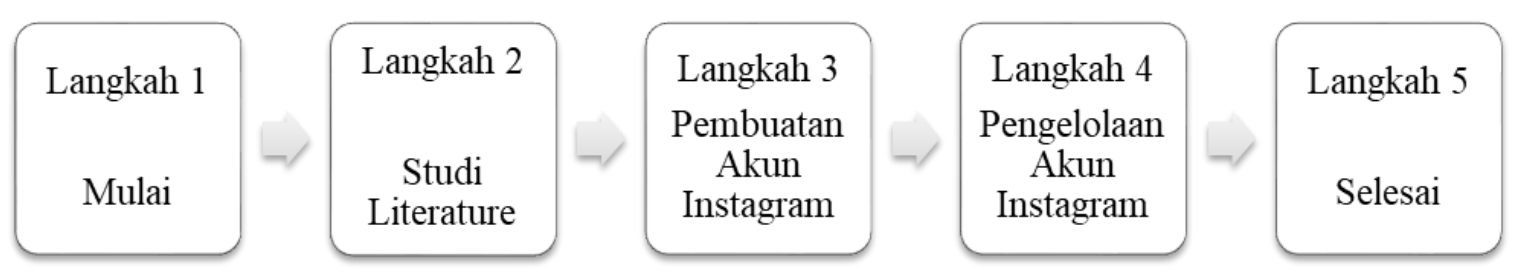

Bagan 1. Alur Pelaksanaan Pengabdian

\section{Hasil dan Pembahasan}

Untuk mengembangkan destinasi wisata yang berada disuatu daerah perlu adanya strategi atau cara yang dilakukan guna untuk menarik minat wisatawan. Salah satu usaha yang dapat dilakukan adalah dengan promosi. Promosi dapat diartikan proses dari mempopulerkan sesuatu yang ingin di ketahui oleh orang banyak. Hal ini dapat dilakukan melalui penggunaan media sosial dengan memposting foto atau video dari keindahan destinasi pariwisata tersebut. Promosi ini tidak memerlukan biaya yang besar dikarenakan mengandalkan koneksi internet yang tidak memerlukan waktu banyak dan ini sangat efisien. Instagaram merupakan salah satu yang efektif digunakan karena media sosial ini memiliki penguna yang banyak dan jangkauan yang luas sehingga dapat dilihat oleh masyarakat dari berbagai kalangan. Sehingga pada pengabdian ini dilakukan pelatihan dalam penggunaan Instagram seperti yang dijelaskan dibawah ini.

\section{Hasil Pembuatan Akun Instagram}

Pada tahapan ini diperkenalkan kepada peserta bagaimana membuat akun instagram dengan mudah di smartphon masing-masing. Pertama sekali peserta diminta untuk mengunduh aplikasi Instagram di Google Play Store untuk telepon genggam yang menggunakan Android dan di App Store untuk iPhone. Setelah aplikasi terinstal, pelatih meminta peserta mengetuk ikon Instagram untuk membukanya. Setelah itu peserta diminta untuk Ketuk Daftar Nomor Telepon untuk Android dan Buat Akun Baru bagi handphone iPhone, lalu peserta diminta memasukkan nomor telepon, lalu ketuk tombol Berikutnya. Selanjutnya peserta diminta membuat nama pengguna dan kata sandi, kemudian pelatih meminta peserta melengkapi info profil usaha parwisata mereka, dan terakhir peserta di minta ketuk tombol Berikutnya, dan akun Instagram selesai dibuat masing-masing peserta. 


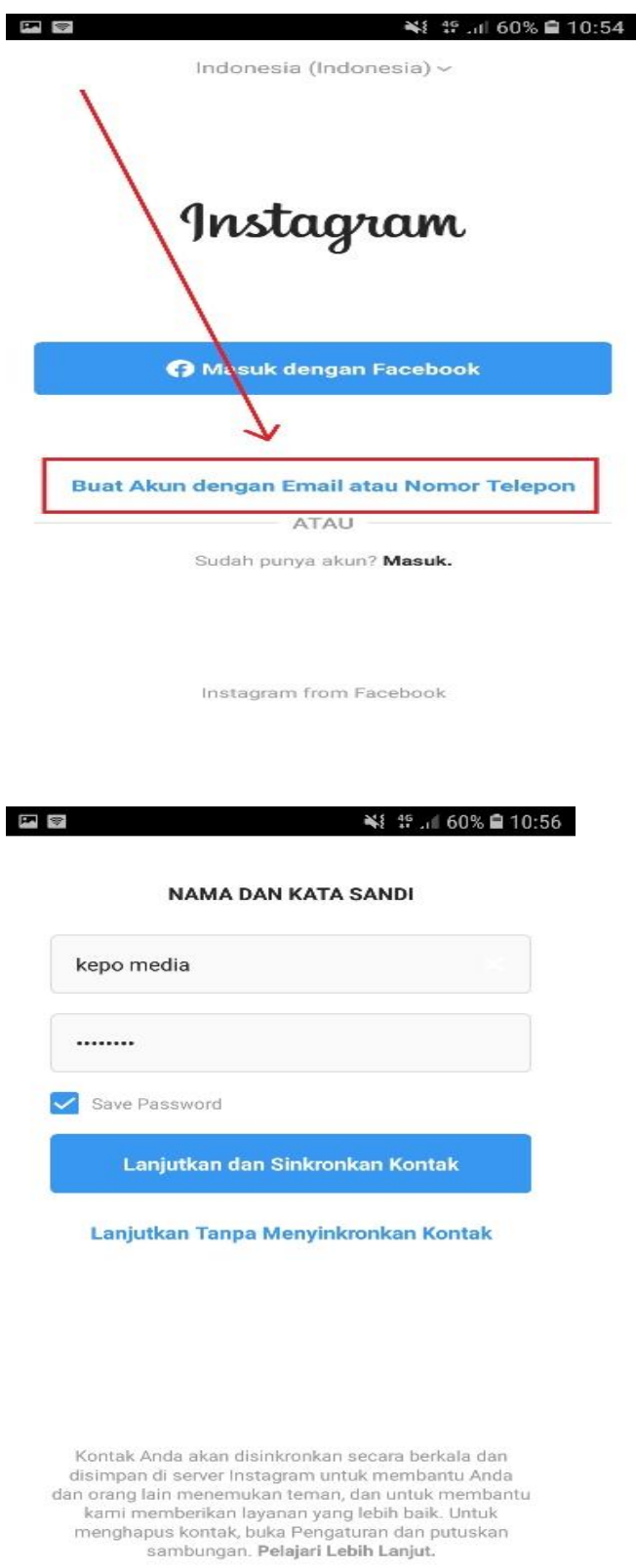

\section{0:54}

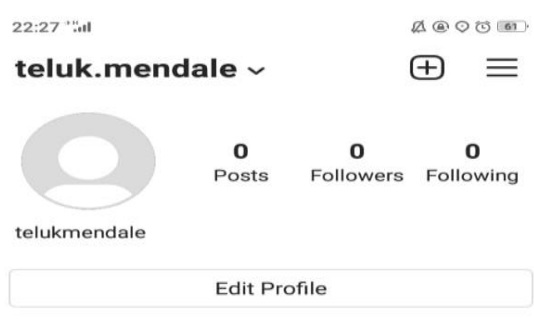

๑ $Q \oplus$ ๑

Gambar 1. Proses Pelatihan Pembuatan Akun Instagram

\section{Pengelolaan Akun Instagram}

Pada tahapan ini pelatih pengabdian memberikan tutorial untuk mengelola akun Instagram yang sudah dibuat, seperti bagaimana:

a. Mengatur latar belakang foto sesuai akun masing-masing

Pada tahapan ini peserta di latih untuk menguasai Instagram dalam mengatur latar belakang photo yang digunakan, seperti a) menjelaskan skema warna yang baik untuk photo yang digunakan, b) membuat tampilan bergaya dan konsisten pada foto akun peserta pelatihan, c) bagaimana tata letak photo yang baik, dan d) bagaimana foto terlihat bersebelahan. Salah satu hasil pada langkah ini seperti photo akun dibawah ini. 


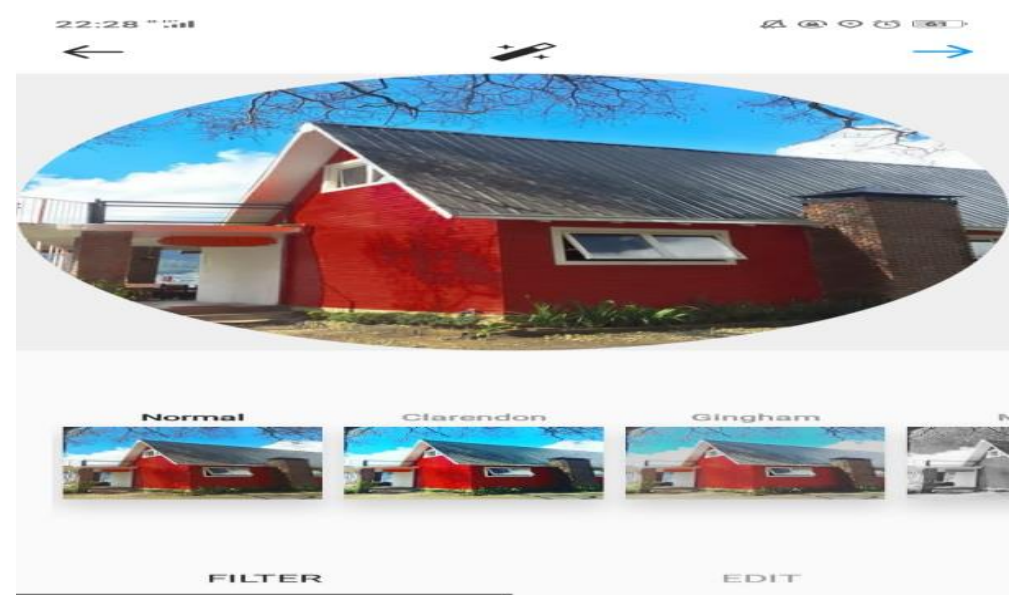

Gambar 2. Proses Mengatur Latar Belakang Foto

b. Apa yang harus di posting dalam akun masing-masing

Pada tahapan ini peserta diberikan pemahaman tentang tema-tema tentang apa saja yang mereka posting. Pemateri menyampaikan kepada peserta untuk memperhatikan poin-poin seperti: a) apa nama akun mereka, b) apa yang mereka suka untuk diposting, c) apa spesialisasi akun mereka, d) memposting photo yang mengatakan tentang akun mereka, tanpa harus katakan sepatah kata pun. Sehingga dengan pemahaman tentang pertanyaan-pertanyaan tersebut peserta diharapkan mampu menerapkannya dengan baik, sehingga dengan memposting apapapun mempunyai makna terhadap pesan yang ditangkap oleh pengikut akun mereka. Pada tahapan ini pemateri memberikan penekanan dan rekomedasi kepada peserta untuk memilih 1-5 hal yang mereka sukai, dan selalu memposting tentang hal-hal tersebut, sehingga hal itu menjadi tema dan ciri yang dimiliki mereka secara spesifik.

c. Bagaimana menambahkan foto dalam pratinjau, posting ulang, buat beberapa foto/video dalam satu posting, tambahkan foto stok gratis menggunakan fitur jelajahi

Pada proses ini pemateri melatih peserta memahami langkah-langkah bagaimana menambahkan foto dalam pratinjau, memposting ulang, membuat beberapa foto/video dalam satu postingan, dan menambahkan foto stok gratis dengan menggunakan fitur jelajahi, adapun contohnya seperti gambar dibawah ini.

\section{Pilih}

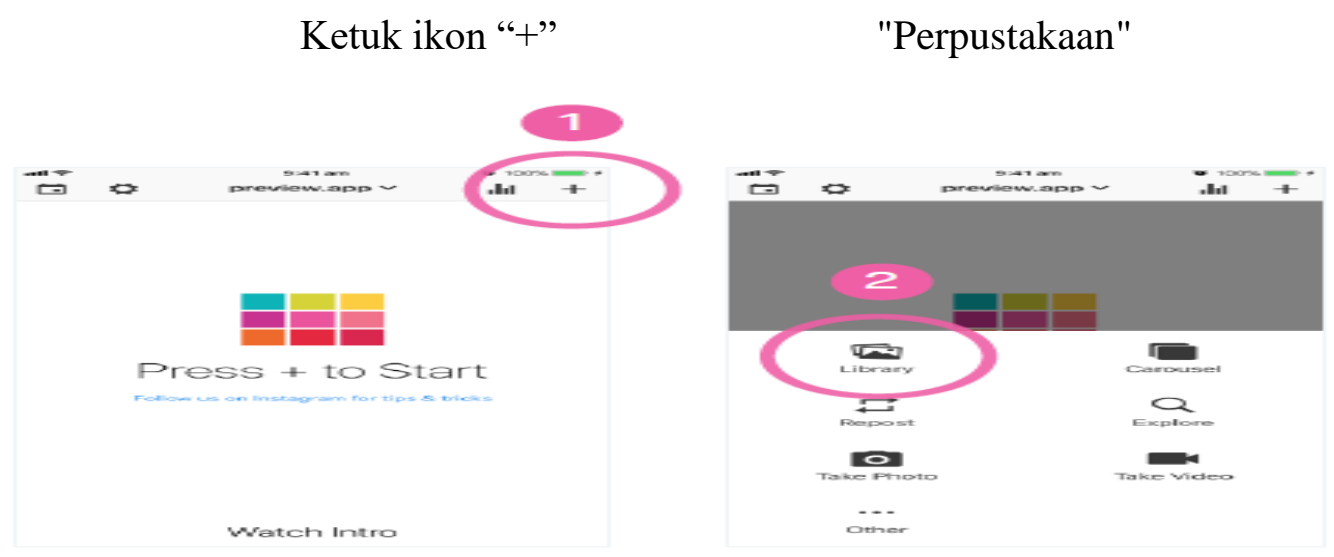

Gambar 3. Proses Untuk Menambahkan Foto Dalam Pratinjau 


\section{d. Hashtag apa yang harus digunakan}

Pada tahapan ini peserta diberi pemahaman tentang bagaimana pengguna Instagram perlu menemukan akun mereka dengan tagar apa yang harus mereka gunakan, dan cara menemukan hashtag terbaik untuk akun mereka. Pemeateri memberikan saran dan masukan yang dirangkum dari berbagai ahli, yaitu ada 6 jenis hashtag yang bisa mereka gunakan yaitu tentang 1) deskriptif , 2) kategori, 3) keahlian khusus, 4) merek, 5) masyarakat/komunitas, 6) lokasi.
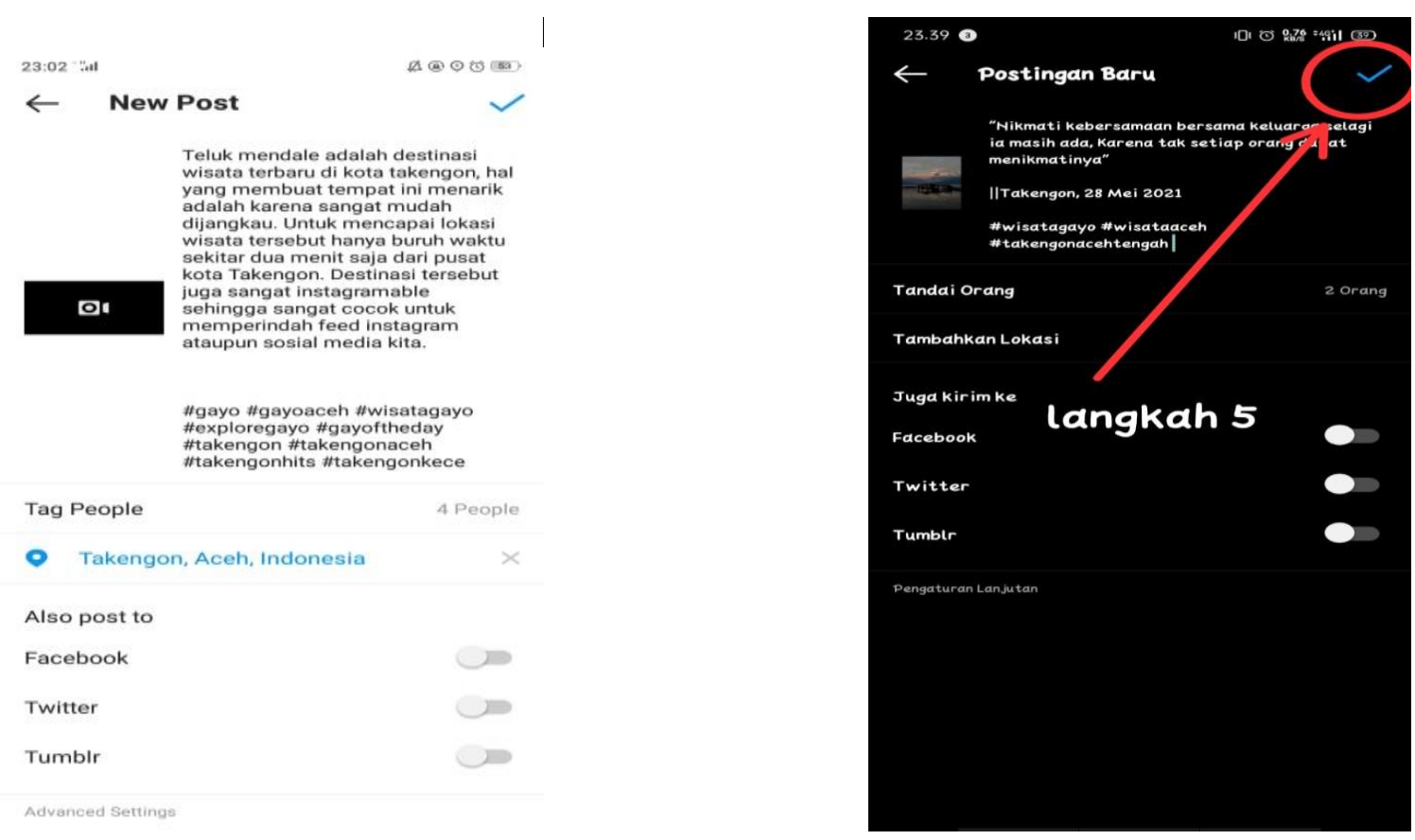

Gambar 4. Contoh Hashtag Dan Proses Untuk Memposting Informasi Akun e. Waktu terbaik untuk memposting informasi akun masing-masing

Dalam hal waktu yang tepat dalam memposting sesuatu, pemateri merekomendasikan memilih jadwal yang sesuai untuk peserta. Menurut ahli sosial media peserta dapat memposting setiap hari 7 postingan, dapat juga memposting setiap hari kerja 5 posting dalam seminggu kerja, memposting setiap 2 hari (Senin, Rabu, Jumat, Minggu) 4 posting, memposting setiap 3 hari (Senin, Kamis, Sabtu) 3 postingan, atau memposting sekali seminggu 1 postingan. Dalam hal ini kuncinya adalah konsistensi dan menjadi rutinitas. Untuk waktu yang tepat dalam memposting adalah saat pengikut anda ada di Instagram. Para ahli juga menyimpulkan waktu terbaik untuk memposting berdasarkan aktivitas di Instagram adalah pada pukul 9 pagi - 11 pagi. Dengan penguasaan langkah-langkah diatas akan berimbas pada meningkatnya dan tumbuhnya pengikut pada akun wisata masing-masing peserta.

\section{Kesimpulan}

Dengan kegiatan dan hasil pelatihan pemanfaatan media sosial sebagai sarana promosi ekowisata ini memiliki dampak yang sangat besar terhadap kemajuan ekowisata yang ada, khususnya di kawasan daerah tanoh Gayo, Aceh Tengah. Seperti yang kita 
ketahui tanoh Gayo memiliki potensi yang amat sangat besar terhadap pengembangan wisatanya. Jadi salah satu cara yang ditempuh untuk keberlangsungan dan kemajuan ekowisata di tanoh Gayo adalah dengan melakukan pendampingan penguasaan sosial media, kepada pihak pengelola wisata didorong untuk memanfaatkan media jejaring sosial sebagai alat pemasaran yang signifikan dalam mengundang wisatawan.

\section{Ucapan Terima Kasih}

Lapaz terima kasih disampaikan untuk segenap pihak yang terlibat dalam aktivitas pengabdian masyarakat ini, dan khususnya kepada pengelola jurnal pengabdian masyarakat As-Salam (JPMA) yang telah mempublikasikan laporan kegiatan ini.

\section{Daftar Pustaka}

Arifianto, E. Y., \& Coiri, M. (2018). Pemanfaatan E-Commerce Dalam Pebelajaran Manajemen Usaha Kecil Dan Menengah. Jurnal Komunikasi Pendidikan, 2(1), 77-85. https://doi.org/10.32585/jkp.v2i1.67

Atiko, G., Ratih Hasanah Sudrajat, Kharisma Nasionalita. (2016). Analisis Strategi Promosi Pariwisata Melalui Media Sosial Oleh Kementerian Pariwisata RI (Studi Deskriptif Pada Akun Instagram @Indtravel). Jurnal Sosioteknologi, 15(3). 378-389. https://media.neliti.com/media/publications/130981-none-daab1153.pdf

Barovih, G., \& Nurussama, N. (2018). Penerapan E-Commerce dan Inovasi Kemasan untuk Produsen Pia Kota Palembang. In Prosiding Seminar Nasional Hasil Litbangyasa Industri (Vol. 1, pp. 118-128). http://ejournal.kemenperin.go.id/pmbp/article/view/4467

BPS RI. (2018). Statistik Wisatawan Nusantara 2018. Statistik Wisatawan Nusantara 2018 (P. 47). Jakarta: BPS RI.

Fatanti, M. N., \& Suyadnya, I. W. (2015). Beyond User Gaze: How Instagram Creates Tourism Destination Brand? Procedia - Social and Behavioral Sciences, 211. 1089-1095. http:// doi.org/10.1016/j.sbspro.2015.11.145.

Fauziah, R., Ike Atikah Ratnamulyani, \& Ali Alamsyah Kusumadinata. (2018). Efektifitas Promosi Destinasi Wisata Rekreasi Gunung Pancar Melalui Postingan Instagram Media Sosial. Jurnal Komunikatio, 4(1). 27-40. https://ojs.unida.ac.id/JK/article/view/1210

Helmalia, H., \& Afrinawati, A. (2018). Pengaruh E-Commerce Terhadap Peningkatan Pendapatan Usaha Mikro Kecil dan Menengah di Kota Padang. JEBI (Jurnal Ekonomi Dan Bisnis Islam), 3(2), 237-246. http://dx.doi.org/10.15548/jebi.v3i2.182

Kurniawati, W. D. N. (2016). Pemanfaatan Instagram oleh Komunitas Wisata Grobogan dalam Mempromosikan Potensi Pariwisata Daerah. Komuniti, VIII(2). 127-144. journals.ums.ac.id/index.php/ komuniti/article/download/2943/2443.

Mahbubani, K. (2013). Top 10 Treads Of 2014. Retrieved from World Economic Forum (Wef): Retrieved on October 05, 2019, http://reports.weforum.org/outlook-14/view/top-ten-trends-categorypage/\%208-the-expanding-middle-class-in- 
asia/?doing_wp_cron=1570288647.5302329063415527343750

Pratiwi, Aprilianti dan M. Girindra Madanacaragni, M. G.(2020). Instagram Sebagai Media Promosi Festival Pariwisata Kota Bogor (Studi Etnografi Virtual Pada Akun @Cgmbogor_Fest). Jurnal Audience: Jurnal Ilmu Komunikasi, 3(1). 117-145. https://doi.org/10.33633/ja.v3i1.3728

Preview App. (2017). Complete Instagram Guide. @ preview.app: Preview App Pty Ltd.

Preview App. (2018). The Complete Instagram Guide for Your Business. @ preview.app: Preview App Pty Ltd.

Purnomo, A. (2018). Pemanfaatan instagram sebagai media komunikasi pariwisata di kabupaten karanganyar (studi analisis deskriptif kualitatif pada akun instagram @explorekabkaranganyar). Skripsi. Surakarta: Universitas Muhammadiyah Surakarta.

Rahmiati, dan Winata, Andrean. (2020). Destination Marketing to Improve Domestic Tourists' Return Intention. International Journal of Applied Sciences in Tourism and Events. 4(2), 86-94. http://dx.doi.org/10.31940/ijaste.v4i2.1979

Ridho, M.R., Simanjuntak, P., Ningsih, D. (2019). PKM Ecommerce, Packaging Design Dan Manajemen Pemasaran Untuk Usaha Kuliner Kota Batam. Wikrama Parahita: Jurnal Pengabdian Masyarakat, 3(1), 21-26. http://dx.doi.org/10.30656/jpmwp.v3i1.1180

Satvikadewi, A.A.I.P., \& Hamim. (2018). Pemanfaatan Media Sosial Sebagai Strategi Komunikasi Untuk Mempromosikan Potensi Lokal Wisata Pulau Bawean. Seminar Hasil Penelitian dan Pengabdian Masyarakat "Hasil Riset dan Pengabdian Masyarakat Sebagai Inovasi Menuju Persaingan Global", Vol. 1, No. 1.

Sukoco, A. (2017). Pemanfaatan Instagram sebagai media Promosi Wisata kebun Buah Mangunan (Studi Deskriptif Kualitatif pada Akun Instagram @kebunbuahmangunanbantul). Skripsi: Universitas Islam negeri Yogyakarta.

Sunarti, S., Puspita, R. H., \& Ernawati, R. (2018). Pengembangan Pemasaran Usaha Kecil Kue Tradisional Rumahan Melalui Media E-Commerce. Jurnal Abdimas Mahakam, 2(2). 85-95. https://doi.org/10.24903/jam.v2i2.377

Trihayuningtyas, E., W. Wulandari., Y. Adriani, I.A.M.P., Sarasvati. (2018) Media sosial sebagai sarana informasi dan promosi pariwisata bagi generasi $\mathrm{Z}$ di Kabupaten Garut. Tourism Scientific Journal, 4(1). 1-22. https://doi.org/10.32659/tsj.v4i1.46

Wibowo, A. T. (2012). Pembuatan Aplikasi E-Commerce Pusat Oleh-Oleh Khas Pacitan Pada Toko Sari Rasa Pacitan. IJNS-Indonesian Journal on Networking and Security, 2(4). 62-67. http://dx.doi.org/10.1123/ijns.v2i4.247 